\title{
Perspectives of peaceful school on vocational school Students: A narrative research
}

\author{
Eko Susanto \\ Universitas Muhammadiyah Metro \\ ekobkummetro@gmail.com \\ Sunaryo Kartadinata \\ Universitas Pendidikan Indonesia \\ profnaryo@gmail.com \\ Ilfiandra \\ Universitas Pendidikan Indonesia \\ Ilfiandra_upi@yahoo.com
}

(Accepted: 15-Maret-2016; Revised: 06-Juni-2016; Published: 28-Juni-2017)

\begin{abstract}
This paper aims to explore the school of peace in the perspective of students in vocational schools. School peace suspected as one of the factors that will determine the formation and behavior of student achievement in school. The narrative method chosen in this study whereas the focus of the study follows the excavation methods offered by Mishler. The study conducted showed that every student has no experience of peace in schools. However, students can receive no peace until he lost condition at meal time. The findings further that there are three things that make students not peaceful, the rules of the school, peer relationships, and the demands of parents and schools.
\end{abstract}

Keywords: peace schools; vocational schools; school rules; peer relationships.

Copyright (C 2017 Universitas Negeri Makassar.. This is an open access article under the CC BYNC-ND license (http://creativecommons.org/licenses/by-nc-nd/4.0/).

\section{INTRODUCTION}

The study of peace in vocational high schools $(S M K)$, especially in engineering program becomes as an irresistible study. SMK Teknik (Technical Engineering High School) that was once known as Sekolah Teknik Menengah/STM (Technical Senior Secondary School) still has negative connotations for some people. Their students are known to be mischievous, brawling, and identical to gender homogeneity that tend to be dominated by male students. School has major implications for students in growing their self-identity in public, family, and ethnic communities. These identities are brought into the school context and an experience after another experience is shaped through their participation in school (Connelly \& Clandinin, 1999, in Chan, 2009). Interactions from different identity backgrounds in this peer group can potentially evoke horizontal conflicts among students. Curriculum demands and learning systems that implement work discipline also contribute to providing pressure. Such conditions should be observed and anticipated as a preventive effort to create a school of peace.

Now, STM probably still connoted as one of the less peaceful schools. But in fact, it is not entirely true. The researchers with their educational background in STM do not feel that way. It indicates that incidents of brawl involving the students are not reasons that make 
them looked unfriendly and not peaceful. In this simple study, the researchers try to explore the values of peace in $S T M$. The study was conducted in one of the leading SMK (STM) in Bandung. The researchers explore the school of peace through observation, interview and openended questionnaire. The highlighted aspects are school services, school environments, student interactions in schools, and students' perspectives on peace schools. The focus of the study is the students' perceptions of peace school. From this study, it will be able to formulate the formation process of student perceptions in STM related to peace schools in a qualitative perspective (Bajaj, 2015, Chen, 2006; Joseph \& Duss, 2009; Kurz, 1981).

\section{Research Context}

STM in Indonesia is a type of school that prioritizes its graduates to become a productive middle-aged, not human burden. Thus, most graduates do not continue to college although there are some who attend favorite public universities in Indonesia. Work orientation is to be the focus of education in STM which then makes the students equipped with a variety of competence to each certain expertise.

SMK (Vocational High School) in Indonesia was originally known as STM (Mechanical Engineering High School). Previously in the 1970s, the government with the Five Year Development Program to One (PELITA 1) initiated to form Sekolah Teknik Menengah (Technical Senior Secondary School). From this idea, a project called "Proyek Perintis Sekolah Teknologi Menengah Pembangunan" (A Pioneer Project of Senior Secondary School of Technology Development) was created. Study period of the school was four years, one year longer than the standard in common schools. At that time, there were eight STM Pembangunan (Senior Secondary School of Development) spreaded in several cities in Indonesia, such as Jakarta, Semarang, Yogyakarta, Surabaya, Ujung Pandang, Bandung, Temanggung, and Pekalongan. Then, in 1974 following the construction of four secondary schools with the name of STM Pertanian (Senior Secondary School of Agriculture) in other areas such as Jember, Boyolali, Tangerang, and Metro.

Ten years later, around 1986, the term of "perintis" (pioneer) was no longer used and changed into STM Negeri Pembangunan (Public Senior Seondary School of Development). Until now, many such schools emerge in Indonesia. In 1997, the government renamed STM into SMK or Sekolah Menengah Kejuruan (Vocational High School). There were many national and international achievements collected by the students and graduates of STM which make our nation proud.

\section{Perspectives on STM's Students}

Several people's opinions addressed to STM's students may have become a phenomenon in Indonesian citizens. At this point, the researchers try to relate from an article on one news portal in Indonesia that $S M K$ or formerly called as STM has less enthusiasts compared to SMA (Senior High School). Several probable reasons for parents to not let their children attend $S M K$ such as fear theirs become as mischievous which is identical to brawl, being untidy, low manners, and so forth. These reasons increasingly worsen public's perception to the students. In fact, this is not entirely true.

The researchers are able to utter in that way because they are graduates of STM. Unfortunately, bad public assumptions still attached to some people until today. The students are considered as follows:

1. Tend to skip classes because prefer to hang out in markets, online game rentals, etc.;

2. STM is regarded for villagers and not fancy. Their students are considered to be artisans and labor. The school is work-oriented after graduation and the graduates do not deserve to attend colleges or universities;

3. Tends to brawl which the image is still very inherent in some people toward them;

4. Bike modifications where the students are also known to ride an odd modified motorcyle or bike with noisy exhaust;

5. Untidy appearance and low mannerism (impolite) which can be seen from their outfits, hairstyles, and no school bag.

One question arises, is it a perception or an assumption that $S T M$ far from being peaceful? This will not be sufficiently and subjectively answered by individuals. It may need empirical evidence to be accounted for, which is expected to be published and becomes as a disproof to some people's assumptions. Previous related researches regarding peace in STM have not been found by the researchers. The most available researches are regarding juvenile delinquency and brawling involving STM's students. 
The description of research context above becomes as the main motivation of the study conducted by the researchers. Every public's perceptions or assumptions toward STM's students indicate that the school is far from the term of 'peace'. The empirical study that will be conducted by the researchers is to explore the potential of peace existed in STM. This study will explore students' perceptions on school of peace and peace in their schools.

\section{RESEARCH METHOD}

This study used a qualitative approach with narrative methods. Narrative inquiry may be done as an effort to deepen the focus of the study conducted. Moreover, it does not only use a single narrative method, but also done to avoid limitations in narrative method. This is considered suitable by the researchers to deepen the focus of peace potential in STM. Through narrative method, it is expected that the researchers will get a real picture in the field, related to the values of peace in STM (Chan, 2009; Hantzopoulos, 2011; King, 2010; Navarro Castro \& Nario Galace, 2008; Patron, Sylvie, 2014; Wintersteiner, 2013).

\section{Setting}

This study was conducted at a Technical Vocational High School (SMK) in Bandung, West Java Province, the western Indonesia. The selected school is SMK Negeri 6 Kota Bandung. The school is chosen based on the easy-accessed location and good passing grade among schools in Bandung which its data recorded in Bandung Education Board's portal. In addition, the school also has ISO certification and operational permit since 1989. Although the researchers admit that the selected school in this study has not represented Bandung City yet. However, it can provide focus overview of this study (Bandung Education Board, 2016).

\section{Research Participants}

Participants in this study were selected by involving school counselors who noted the elements of randomization and recommendations from the school. The participants were taken from eleventh grade students, but only one class selected that is from Teknik Gambar Bangunan department (Building Image Engineering). The number of participants are 21 total students with 6 female studens and 15 male students (Cremin, 2015).

\section{Data Collection dan Analysis}

Data collection in this study was conducted by visiting the school and distributing an open-ended questionnaire to the students. In the questionnaires, students were asked to tell about incidents or events that made themselves feel uneasy. The story is a non-peaceful incident or event in a school setting, for example with friends, teachers, school carers, cafeteria owners, heads of workshops or laboratories, heads of study programs/departments, school administration's staff, and so on. The researchers also conducted interviews and informal conversations with the students involved in filling the questionnaires. Interviews were conducted to obtain further information which is not found in the questionnaires. Observations were held in school by checking the school environment. The school's response and acceptance were also the parts of the observation activities. The informal conversations including asking and greetings were done to students and teachers throughout the school environment as part of observation activities as well (Chan, 2009; Chen, 2006; Garza, 2015; Goulah \& Urbain, 2013; Hantzopoulos, 2011; Kurz, 1981; Suter, 1988).

The researchers try to present the findings of this simple study into two view contexts of school's peace. The first is the potential and efforts of the school in the creation of a peace culture. The second is the exploration of school of peace based on the questionnaires, interviews, and observations. These two contexts will be tested narratively to explain the term of school of peace in STM. The analytical approach to organize the research findings is presented in four categories. Orientation-the description of the setting and characteristics, abstraction-the summary of events or incidents from the participants' stories, complication-evaluative comments on events and conflicts, resolution-the description of the results obtained from the stories and conflicts (Mishler 1986, p 236-237 in Chen, 2006).

\section{RESULT AND DISCUSSION Orientation}

SMK Negeri 6 Bandung is a public vocational high school located in Jalan Soekarno-Hatta, Kompleks Riung Bandung, RT 05 RW 10, Kelurahan Cisaranten Kidul, Kecamatan Gedebage, Bandung City, West Java Province, Indonesia. The study period in SMK 
Negeri 6 Bandung is taken within three years of lessons, ranging from class X to class XII, as in general period of vocational high school in Indonesia. SMK Negeri 6 Bandung was established in 1953 under the name of Sekolah Guru Pengajar Teknik/SGPT (School of Engineering Teachers) located at Jalan Dr. Rum Number 17. In 1965, SGPT was renamed into STM Instruktor. Later in 1979, it was renamed into STM Negeri 5 Bandung with the location at Jalan Pajajaran Number 92, Bandung. Starting from the academic year 1992/1993, the building of STM Negeri 5 Bandung moved from Jalan Pajajaran Number 92, Bandung into Jalan Soekarno-Hatta, Kompleks Riung Bandung. Furthermore, in the academic year 1996/1997, STM Negeri 5 Bandung changed its name again into SMK Negeri 6 Bandung issued by a letter of decision from Ministry of Education and Culture Number 036/O/1997.

The researchers' arrival to the school becomes as their first experience in order to conduct narrative study and visit the school as the research location. When arriving at the front gate, the researchers were welcomed by a school guard with a unique local welcome. Heading to the parking lot, we can seen many school facilities such as buildings, parks, halls, sport field, classrooms, all of which are very representative. By its appearance, the school has excellent educational facilities and infrastructures.

When heading to the administrative room, the visitors will be greeted with a comfortable waiting room. It is also a room for trophies display, charters, and awards featuring the school and students achievement. When the researchers asked to the staff, the answer was given with the similar distinctive dialect of the school guard's previously. From this point, the researchers assume that schools generally apply the cultural values of the local area. When crossing the classrooms, workshops, and laboratories, its atmosphere is very quiet. On the contrary with the assumption from some people that STM's students are troublemakers.

In general, the students who meet faceto-face with the researchers come from tribes, customs, and cultures that are relatively homogeneous. It seems that the cultural homogeneity in a community also contributes to the creation of a peaceful atmosphere. A sense of togetherness in a cultural values system and the process of minority enculturation also contribute to create a peaceful atmosphere (Gunderson, 1937; Harber \& Sakade, 2009; Lombardo \& Polonko, 2015; Navarro Castro \& Nario Galace, 2008).

The habituation of work discipline in vocational high school has also become a medium for establishing compliance with regulations in public. STM is also known for its high discipline education which closely related to the code of occupational safety ethics. If abandoning occupational safety regulations, it can harm ourselves and others. This characteristic is highly embedded in STM, as a consequence of curriculum orientation in creating graduates who are ready to work (Jahnukainen \& Helander, 2007; Mndebele \& Dlamini, 2008).

\section{The Comparison of Vocational-Technical Schools in Indonesia from Other Countries}

\section{Indonesia}

How do vocational school managed in other countries? This becomes important as a comparison to vocational schools in Indonesia and can be an inspiration for quality improvement. Member States of Southeast Asian Minister of Education Organization (SEAMEO) agreed to increase cooperation in the field of vocational education, one of them through the exchange program of vocational students. The student exchange program is called "Student Mobility", and has been running for several years, involving hundreds of vocational students from various ASEAN countries studying in other ASEAN countries. Student Mobility has been in existence since 2011 starting with Thailand contingent at SMK in Solo, Central Java. Until now, there are 135 vocational schools that follow the program of Student Mobility (Directorate of Vocational Education, 2016).

Furthermore, Student Mobility program facilitates each ASEAN member country to be able to change experiences and share best practice in vocational education. Southeast AsiaTechnical and Vocational Education and Training (SEA-TVET) is expected to become a forum for students exchange as a means of sharing knowledge and technology and giving chances for apprenticeship or work in ASEAN member countries as an effort to improve the quality of skilled labor (Directorate of Vocational Education, 2016).

Ministry of Education and Culture 
(Kemendikbud) strengthens the role of vocational education as an implementation of Nawa Cita's priority agenda proclaimed by the Government. In 2016, Kemendikbud built 341 school buildings to increase the quantity of facilities and infrastructure of $S M K$ throughout Indonesia. Associating with the local government, Kemendikbud will increase the number of vocational teachers by considering the recent total of 270 thousand teachers. Also, several efforts to improve the students' quality and vocational school graduates, one of them is preparing 1,650 schools to become Professional Certification Institution $(L S P)$ and SMK graduates can be better equipped and more competent in joining work field, especially in the era of open competition of the ASEAN Economic Community (MEA). The graduates of $S M K$ are strived to be required for having certification of worthiness with international standard in order to compete with other countries. At least having a certificate of competence recognized by MEA (Kemdikbud, 2016).

We expect that what is programmed by the government is in line with the improvement of learning quality. In relation to the research focus of peace in STM, at least the peace aspect of the learning process is also considered. To compare with other countries, not only ability to compete internationally which has to be prioritized, but also strong mentality. The competence of vocational school graduates needs to be built in a peaceful atmosphere that starts from school environment. This is an effort to reinforce soft skills in making peace with themselves and the environment in global competition. It is also meant to avoid a great disappointment and unfair competition by dealing with a non-peaceful situation.

\section{Finland}

For Finnish citizens, their belief in education is strongly embodied in national policy (Rinne \& Kivirauma, 2003). Vocational school becomes as an alternative for school dropouts in East Finland (Jahnukainen \& Helander, 2007). In 2001, many young people between the ages of 15-24 studied in Finland compared to other EU countries (Järvinen, 2001; Jahnukainen \& Helander, 2007). Several programs are made by the Finnish government to overcome dropout problems, such as courses that emphasize on vocational and job skills (Bullis \& Fredericks, 2002). Integrated extramural program
(Jahnukainen \& Helander, 2007), a comprehensive school and a vocational school become as pedagogical support services prepared by the government to overcome the problem of dropouts (Jahnukainen, 2001; Jahnukainen \& Pynnönen, 2003; Jahnukainen \& Helander, 2007).

Finnish government's commitment is about to make peace mission in education process. This action is to anticipate productive young people who drop out of school, which if left abandoned can lead to social problems, such as crime, unemployment, and lowering the young workers' quality. All activities programmed by Finnish government refer to strong theories (Jahnukainen \& Helander, 2007) and are based on the paradigm of social pedagogy (Hamalainen \& Komonen, 2003). Programmed actions by the government are obviously tangible manifestations to create a peaceful education. That is why the world recognizes that the best education lies in Finland.

\section{Egypt}

Vocational education in Egypt is intended to overcome young people unemployment in their productive ages. Education in Egypt began with a five-year primary school and a three-year preparatory school. This is a compulsory school for children aged 6-14 years. After that, there are a three-year public school and a vocational school. The vocational school is divided into two, that is a three-year vocational school qualified as "technicians" for the industrial, agricultural, and commercial sectors. Then vocational school with five years of advanced vocational / technical secondary school with "First Technician" qualification. Unfortunately, vocational school students in Egypt are those who do not reach certain limits on selection in public schools set by the government.

Such conditions can lead to unresolved perceptions in society for vocational schools in Egypt. There is a different kind of strata attached to the government's policy system. Public assumption on vocational school as a second alternative can create a non-peaceful situation within the students. At the same time, it can be a source of further problems that hinder the process of education in vocational schools (ElHamidi, 2006; Firer, 2008; Maytyok, Thomas, Senehi, Jessica, Byrne, 2011).

\section{Abstraction}


The key to success in vocational school is teacher competence and their attitude. Vocational teachers are expected to be concerned along with rapid technological developments and changes. In many developing countries, the role of vocational education to form students' knowledge, skills, and attitudes as the aspects that also need to be considered. The attitude and motivation of teachers in vocational schools have an important role to improve the performance of $S M K$ 's graduates. Teachers' motivation in vocational education institution is an important factor in achieving goals. Here are several factors relating to teacher motivation in developing vocational programs as follows: (1) care with students; (2) concern to professional development; (3) eager to be more up-to-date on technological progress (Al-Ali 2005; Mndebele \& Dlamini, 2008).

Another cause that lowers the selfacceptance of vocational school students is the negative stigma in the public that attached to the school. Some students feel unfortunate to attend vocational school because failing to pass the test in public school (Rojewski and Park, 2005). It seems that this stigma is similar for vocational schools in Indonesia. Although the schools have potential to reduce unemployment and increase productivity (Mndebele \& Dlamini, 2008). This kind of excellence is not known by many people, that vocational schools also have implications in social life. From the results of empirical research shows that there is connection among family social status, individual's social environment, academic achievement, and employment options (Tien and Lin 1994, 37).

\section{Findings and Resolution}

Findings in the field from 21 students showed three things that made them feel nonpeaceful at school, for instance, school rules, peer conflicts, and demands between parents and teachers at school.

\section{School Rules}

Vocational schools are known for their high discipline. This is a habituation for students which there is a demand of high discipline in work fields. The school's policy defined as a rule in school turns out to be a stressor for students. It is also added by the implementation of school rules that involve the subjectivity of each different teacher. In line with that, one student stated:

\begin{abstract}
"I feel uncomfortable with teachers who are too overprotective, especially asking for their permission if I want to hang out in off day. If we skip the permission, they will make a phone call with our parents."
\end{abstract}

Such statement is written by almost students in the story sheets. The demands of the school rules may not be realized by teachers that can change their attitude from teacher as a friend and parents at school becomes as a disciplinary enforcer. In the view of the researchers, it may be necessary to mobilize school rules that have a touching morphology for the students. Pursuing this further, there is an interesting statement from almost students which agreed with the previous statement and an optimistic ending:

"Yes, this is life. It has to be dealt with problems."

This shows a presence of spiritual process which raises the students' acceptance to the circumstances that befall them. At this point, there is something that can be done by the teacher or school to build a good communication with the students. This is used as a means to avoid misunderstanding in the implementation of school rules. There may be a communication style of school rules that emphasize intimacy among teachers-students or school-students. In fact, the school has informed the rules through interesting infographics. The infographics are made as commonly found in bookstores and supermarkets. Such efforts are innovative in which the researchers have never seen before in other schools.

In some stories, there are several students that still write down the figure of teachers as "Guru Danger" (killer teachers). They are teachers who tend to be angry, scary, and must be avoided as possible as can by the students. The researchers find this phenomenon almost in every school, not only in vocational schools. Perhaps we need to learn from teachers in Finland who are never angry and give homework. If this right is implemented in Indonesia, it may take a long process. At least we expect the classroom learning will bring a peace mission that can make students feel comfortable. Supposedly, this kind of implementation can be started partially, from the commitment of each teacher. Why is this important? Because the performance of vocational school graduates is 
also determined by teachers' or instructors' attitude at school.

However, almost every student has a high resilience to survive in uncomfortable situations. The reality also shows from the students' stories that some said their school is the most comfortable and interesting place for them. Counting from 21 stories, only one student asks for a class move and leaves the school. Even so, the school dropouts are not related to the school rules but caused by other problems. This means that the school still has potential situations to bring school rules in a careful atmosphere among teachers, schools, and students (Tien and Lin 1994, 37).

\section{Peer Relationship}

Peer conflicts rarely occur and are not serious ones. But one of the students' stories states that her relationship is less harmonious with friends. This relationship causes uncomfortable feeling to stay in class. There is only one story of this kind from 21 stories submitted by the students. Here is the statement from the female student:

"There is male student who act differently and awkwardly to me. This is what makes me uncomfortable for staying in the class."

The same statement is also conveyed by a male student. From this point, the researchers discover the students who have less harmonious relationship. The assumption of this lack of harmony occurs between the opposite sex who have a special relationship "dating". In addition to this kind of story does not exist. This fact shows that the peace of peer relationships in the class is very good.

There are several related stories to less harmonious relationships with friends in the classroom. Surprisingly, some of these stories point to one same student, whom they perceive to be less sociable. However, it was stated that one student eventually dropped out of school. According to students' stories, this kind of situation happened temporarily (Mndebele \& Dlamini, 2008).

\section{The Demands from Parents and Teachers at School}

The inequalities of parents and teachers' demands at school turn out to be the second highest stressor after school rules. This makes students feel uncomfortable at school or home. One of the students' statements:
"We come home from school in late afternoon, but the school asks to go straight home. We also need refreshing."

Here are a statement from another student:

"We are told to go home immediately because it is already late afternoon when the school is over. Also, if we want a holiday or hang out even in day off, we need to ask for permission from our homeroom teacher. We feel depressed, everywhere we go always needs to be monitored."

Another addition from another student's statement:

"When I arrive home after school, my dad straightly asked me to help him work."

There is one sad story from a student detected by the researchers:

"I was late in replying my teacher's message by phone and got scolded by him. It is because I had to help my dad worked in the printing house."

Stories and statements above can be good reflections for the researchers. From the first and second statements, a homeroom teacher has full responsibility for their students. But the implementation of these responsibilities may be considered as gradation that raises students' negative perceptions to them. This negative perception abolished peace on student relationships with the teachers. The third statement implies boredom with school and home routines that make them feel the need to get refreshing outside. Perhaps from these stories, the school can make family gathering program to cast out the boredom from home and school routines as the gratitude action for the teachers and parents. This is important in order to avoid miscommunication between teachers and students. In addition, personal data of students also need to be understood more deeply as a treatment consideration for each student.

Considering the socio-economic background of the students is certainly intended for the implementation of school programs. Most students write down their parents job as selfemployer/home industry, trader, security, freelance workers, and hotel's staff. A synergy between school and parents becomes as psychological support for the students. A sense of comfort and peace at school and home has been a main supporter of the programs' success to produce graduates who are competent and 
highly competitive (Brantmeier, 2012; Chen, 2006; Mndebele \& Dlamini, 2008; Peou, 2011; Suter, 1988).

\section{CONCLUSION AND SUGGESTIONS}

Based on the description above, the researchers made a personal note to be applied in the schools where the researchers teach. To actualize the school's peace, it needs cooperation among school, parents, and students. This needs to be supported by intense and reconciled communication. It is very possible to enforce school rules without threatening. Also, it surely needs to understand the students' background as treatment consideration for each student. It is possible that many school's programs are not known by the researchers because not revealed by the used narrative method. Building collective awareness of the need for parents and school supports becomes as the school vision to bring students' success.

From this study, it can be concluded as follows: The first is relating to the perception of $S M K$ 's students toward school's peace. Each student in general has an uncomfortable experience at school. It is related to school and teacher regulations, peer relationships, and demands from parents and school. Even so, the experiences commonly occured a year ago when the students were in tenth grade. Many students' expectations were requested to be understood by school and parents. To respond, it has to be a close communication between school and students. Generally, students can solve their problems even though they never tell to teacher and parents. In response to this, there needs to be a close communication between the school and students. Generally, the students can solve their problems even though they never tell their parents.

The second is, school and the attitudes of teachers and parents are expected to reconcile students. This is very important because it affects the students' behavior. Teachers and parents can build a synergistic communication that supports students' comfortness in learning. Schools, parents, and teachers provide opportunities for students to express their wishes and expectations. Thus, it is needed to create a peaceful and comfortable atmosphere in learning.

\section{REFERENCES}

Anonymous.(2016). 8 STM Pembangunan Cikal

\author{
Bakal Seluruh SMK di Indonesia. \\ Retrieved from \\ http://www.ilmusipil.com/8-stm- \\ pembangunan-cikal-bakal-seluruh-smk-di- \\ indonesia).
}

Al-Ali, S. 2005. Instructor's key vocational education competencies in Kuwait: The Department of Production Engineering in the College of Technological Studies. International Journal of Vocational Education and Training 13, no. 2: 65-79.

Bullis, M. \& Fredericks, H. D. (2002) Vocational and transition services for adolescents with emotional and behavioural disorders: strategies and best practices (Champaign, IL, Research Press).

Bajaj, M. (2015). "Pedagogies of resistance" and critical peace education praxis. Journal of Peace Education, 0201(September), 1-13. http://doi.org/10.1080/17400201.2014.9919 14

Brantmeier, E. J. (2012). Social justice, peace, and environmental education: transformative standards. Journal of Peace Education (Vol. http://doi.org/10.4324/9780203879429

Chan, E. (2009). Living in the Space Between Participant and Researcher as a Narrative Inquirer: Examining Ethnic Identity of Chinese Canadian Students as Conflicting Stories to Live By. The Journal of Educational Research, 103(2), 113-122. http://doi.org/10.1080/00220670903323792

Chen, F. (2006). Chinese parents 'perspectives on home - kindergarten partnership: A narrative research, 37, 95-105.

Cremin, H. (2015). Peace education research in the twenty-first century: three concepts facing crisis or opportunity? Journal of Peace Education, 0201(September), 1-17. http://doi.org/10.1080/17400201.2015.1069 736

Direktorat Pembinaan SMK. (2016). Pertukaran Pelajar SMK Antar Negara ASEAN akan ditingkatkan. Retrieved from http://psmk.kemdikbud.go.id/konten/1567 /pertukaran-pelajar-smk-antarnegara-aseanakan-ditingkatkan.

El-Hamidi, F. (2006). General or Vocational Schooling? Evidence on School Choice, 
Returns, and "Sheepskin" Effects from Egypt 1998. The Journal of Policy Reform, 9(2), 157-176. http://doi.org/10.1080/13841280600772861

Firer, R. (2008). Virtual peace education. Journal of Peace Education, 5(2), 193-207. http://doi.org/10.1080/17400200802264479

Garza, N. L. (2015). Education for Peace in the Mexican context. Canadian Journal of Latin American and Caribbean Studies, 3663(June), 37-41. http://doi.org/10.1080/08263663.2015.1044 720

Goulah, J., \& Urbain, O. (2013). Daisaku Ikeda's philosophy of peace, education proposals, and Soka education: convergences and divergences in peace education. Journal of Peace Education, 10(3), 303-322. http://doi.org/10.1080/17400201.2013.8480 72

Gunderson, S. (1937). Peace and the Schools. The Social Studies, 28(7), 309-312. http://doi.org/10.1080/00220973.1934.1101 6207

Hämäläinen, J. \& Komonen, K. (2003) Työkoulumalli ammatillisessa koulutuksessa [Activity school model in vocational secondary education] (Activity School of East Finland Publication No. 2) (Kuopio, Kuopion yliopisto \& Kaprakan aikuiskoulutuskeskus).

Hantzopoulos, M. (2011). Institutionalizing critical peace education in public schools: A case for comprehensive implementation. Journal of Peace Education, 8(3), 225-242. http://doi.org/10.1080/17400201.2011.6213 64

Harber, C., \& Sakade, N. (2009). Schooling for violence and peace: how does peace education differ from "normal" schooling? Journal of Peace Education, 6(2), 171-187. http://doi.org/10.1080/17400200903086599

Jahnukainen, M., \& Helander, J. (2007). Alternative vocational schooling for the dropped-out: students' perceptions of the Activity School of East Finland. European Journal of Special Needs Education, 22(4), 471-482.

http://doi.org/10.1080/08856250701650110

Jahnukainen, M. \& Pynnönen P. (2003) (Eds) Ammatillisen erityisopetuksen kentällä [In the field of vocational special education] (Activity School of Eastern Finland Publication No. D3/2003) (Saarijärvi, Häme Polytechnic).

Järvinen, T. (2001) Koulutusjärjestelmän yksilöllistyminen ja valinnanvapaus [The individualization of the educational system and the right of choice], in: T. Kuure (Ed.) Aikuistumisen pullonkaulat [Living conditions of young people. Bottlenecks on the way to adulthood] (Pieksämaki, Advisory Council for Youth Affairs, Finnish Youth Research Network and Stakes).

Joseph, P. B., \& Duss, L. S. (2009). Teaching a pedagogy of peace: a study of peace educators in United States schools in the aftermath of September 11. Journal of Peace Education, 6(2), 189-207. http://doi.org/10.1080/17400200903086615

King, K. P. (2010). Advancing Educational Podcasting and Faculty Inquiry with a Grounded Research Model: Building on Current Mixed-Methods Research across Contexts. The Journal of Continuing Higher Education, 58(3), 143-155. http://doi.org/10.1080/07377363.2010.4917 78

Kurz, W. (1981). Can the School Teach Peace? Pedagogical and Systematic - Theological Perspectives. British Journal of Religious Education, 4(1), 3-16. http://doi.org/10.1080/0141620810040102

Lombardo, L. X., \& Polonko, K. a. (2015). Peace education and childhood. Journal of Peace Education, 12(2), 182-203. http://doi.org/10.1080/17400201.2015.1046 424

Maytyok, Thomas, Senehi, Jessica, Byrne, S. (2011). Critical Issues in Peace and Conflict Studies: Theories, Practice and Pedegogy.

Mediana Agita Pratiwi, rinjanisasak. (2016). Anggapan Masyarakat Soal Anak STM di Indonesia. Retrieved from http://log.viva.co.id/news/read/676568-5anggapan-masyarakat-soal-anak-stm-diindonesia.

Mndebele, C. B. S., \& Dlamini, E. (2008). High school vocational programmes: self-reported perceptions of vocational 
teachers in Swaziland. Journal of Vocational Education \& Training, 60(3), 315-325.

http://doi.org/10.1080/13636820802305660

Navarro Castro, L., \& Nario Galace, J. (2008). Peace Education: A Pathway to a Culture of Peace. Center for Peace Education, Miriam College, Quezon City, Philippines.

Patron, Sylvie. (2014). On the Epistemology of Narrative Theories. Wikipédia, a Enciclopédia Livre, 47(1). Retrieved from https://pt.wikipedia.org/w/index.php?title= Micro-história\&oldid=38081390

Peou, S. (2011). Peace and Security in the AsiaPacific: Theory and Practice. Pacific Affairs (Vol. http://doi.org/10.1355/cs32-3j

Rinne, R. \& Kivirauma, J. (2003) Koulutuksen ja syrjäytymisen muuttuva yhteys [The changing connection of education and social exclusion], in: R. Rinne \& J. Kivirauma (Eds) Koulutuksellista alaluokkaa etsimässä. Matala koulutus yhteiskunnallisen aseman määrittäjänä 1800- ja 1900luvuilla[The historical formation of 'educational lower class': poor education as the denominator of social position and status in the 19th and 20th centuries in Finland] (Research in Educational Sciences No. 18) (Turku, Finnish Educational Research Association), 13-78.

Rojewski, J.W., and J.H. Park. 2005. Secondary vocational education in South Korea: Addressing challenges and seeking solutions. International Journal of Vocational Education and Training 13, no. 2: 7-29.

Suter, K. D. (1988). Australian peace institutes. Medicine and War, 4(4), 211-212. http://doi.org/10.1080/07488008808408826

Wintersteiner, W. (2013). Building a global community for a culture of peace: the Hague appeal for peace global campaign for peace education (1999-2006). Journal of Peace Education, 10(2), 138-156. http://doi.org/10.1080/17400201.2013.7902 50

Tien, C.J., and Y.D. Lin. 1994.A study of parental attitudes vocational education in Taiwan. International Journal of Vocational
Education and Training 2, no. 2: 37-50.

Wikipedia.(2016). SMK Neheri 6 Bandung.Retrieved from https://id.wikipedia.org/wiki/SMK_Negeri_ 6_Bandung.

Wikipedia.(2016). Sekolah Teknik Menengah. Retrieved from https://id.wikipedia.org/wiki/Sekolah_tekni $\mathrm{k} \_$menengah. 